\title{
Restricted Use Pesticides for Use in Florida ${ }^{1}$
}

\author{
Frederick M. Fishel ${ }^{2}$
}

\section{Background}

All pesticides are classified according to their toxicity, use pattern, and environmental effects. The two main classifications set out by the US Environmental Protection Agency (EPA) are unclassified use and restricted use, though unclassified pesticides are commonly referred to as general use pesticides. A restricted use pesticide is one that is for retail sale to and use by only certified applicators or persons under their direct supervision and only for those purposes covered by the applicator's certification. This document provides a listing of pesticide active ingredients registered in Florida that are classified as restricted use and the reason(s) for their restricted use classification.

\section{Use Classification}

The EPA classifies a pesticide as restricted use if use of the pesticide might result in an adverse effect on human health and/or the environment if used incorrectly. However, application by trained persons following label directions would protect against such an effect. The EPA evaluates the risk of using the pesticide in this decision, with risk considered to be the chance of harmful effects to human health or to ecological systems resulting from exposure to an environmental stressor. A similar term, but with a different meaning, is "hazard." A hazard is a situation that poses a level of threat to life, health, property, or environment. Most hazards are potential, with only a theoretical risk of harm; however, once a hazard becomes "active," it can create an emergency. Hazard and possibility interact together to create risk. In classifying a pesticide, the EPA considers:

- the toxicity of the pesticide;

- the way in which the pesticide will be used; and

- the effect of the pesticide on the environment.

When a pesticide is classified as restricted, the label will state "Restricted Use Pesticide" at the top of the front panel. Below this heading may be a justification for the restricted use classification (Figure 1).

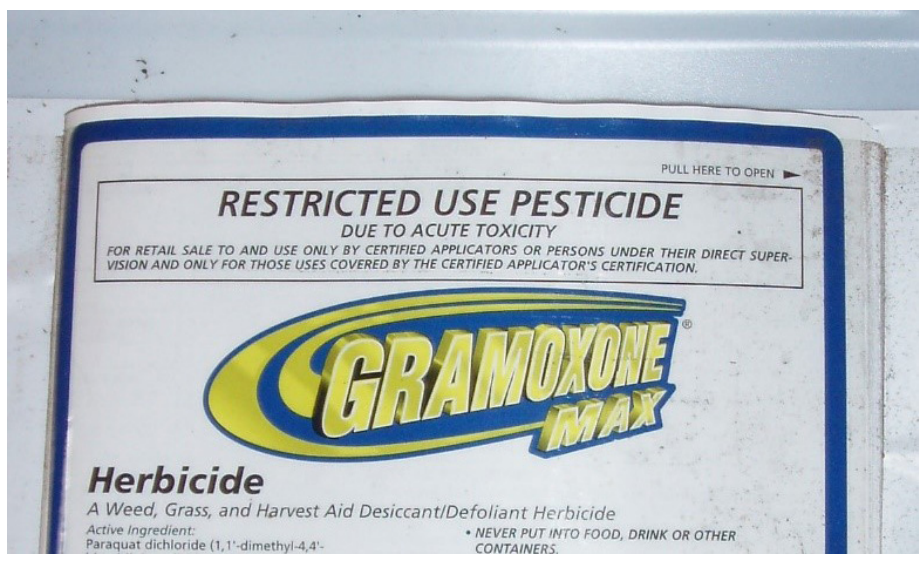

Figure 1. Restricted use product, labeled as such because of its risk of acute toxicity to the applicator or nontarget organisms.

Credits: Frederick M. Fishel, UF/IFAS

1. This document is PI-36, one of a series of the Pesticide Information Office, UF/IFAS Extension. Original publication date March 2005. Revised September 2019. Visit the EDIS website at https://edis.ifas.ufl.edu for the currently supported version of this publication.

2. Frederick M. Fishel, professor, Agronomy Department, and director, Pesticide Information Office; UF/IFAS Extension, Gainesville, FL 32611.

The use of trade names in this publication is solely for the purpose of providing specific information. UF/IFAS does not guarantee or warranty the products named, and references to them in this publication does not signify our approval to the exclusion of other products of suitable composition. Use pesticides safely. Read and follow directions on the manufacturer's label.

The Institute of Food and Agricultural Sciences (IFAS) is an Equal Opportunity Institution authorized to provide research, educational information and other services

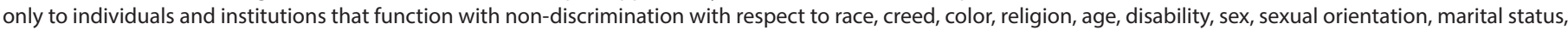
national origin, political opinions or affiliations. For more information on obtaining other UF/IFAS Extension publications, contact your county's UF/IFAS Extension office. U.S. Department of Agriculture, UF/IFAS Extension Service, University of Florida, IFAS, Florida A \& M University Cooperative Extension Program, and Boards of County Commissioners Cooperating. Nick T. Place, dean for UF/IFAS Extension. 
Although there is a federal list of restricted use active ingredients determined by the EPA, some states have their own lists of restricted products. Florida follows the federal guidelines for determining if a product is restricted. To purchase and apply restricted use pesticides, a person must be certified and licensed in the state of Florida. Table 1 provides a listing of active ingredients registered in Florida that have some or all formulations/products classified as restricted use, the pesticide type, and the reason for restriction. Keep in mind that although some active ingredients are formulated into products that are classified as restricted use, other formulations containing the same active ingredient are not classified as such. Thus, some products containing these active ingredients are available to the general public, including homeowners. To search all pesticide active ingredients registered in Florida, go to the public National Pesticide Information Retrieval Site (NPIRS) site at http://npirspublic.ceris.purdue.edu/state/ state_menu.aspx?state=FL. 
Table 1. Federally listed restricted use pesticide active ingredients that have some or all formulations/products registered in Florida by pesticide type, and the reason for restriction.

\begin{tabular}{|c|c|c|}
\hline Pesticide type & Active ingredient & Reason(s) for restriction \\
\hline Avicide & 4-aminopyridine & Inhalation toxicity to humans \\
\hline \multirow[t]{10}{*}{ Fumigants } & Aluminum phosphide & \multirow[t]{10}{*}{ Inhalation toxicity to humans } \\
\hline & Chloropicrin & \\
\hline & Dazomet & \\
\hline & 1,3-Dichloropropene & \\
\hline & Dimethyl disulfide & \\
\hline & Magnesium phosphide & \\
\hline & Metam-sodium & \\
\hline & Metam-potassium & \\
\hline & Methyl bromide & \\
\hline & Sulfuryl fluoride & \\
\hline Fungicides & Fentin hydroxide & $\begin{array}{l}\text { Carcinogenicity, potential for affecting fetal development, and high acute } \\
\text { toxicity to humans }\end{array}$ \\
\hline \multirow[t]{7}{*}{ Herbicides } & Acrolein & High acute toxicity \\
\hline & Atrazine & Groundwater and surface water contamination concerns \\
\hline & Dicamba & Registration condition ${ }^{1}$ \\
\hline & Diclofop-methyl & Carcinogenicity in laboratory mice, and eye irritation \\
\hline & Paraquat dichloride & Acute toxicity to humans \\
\hline & Picloram & May injure susceptible nontarget plants \\
\hline & Propyzamide & Production of tumors in laboratory animals \\
\hline \multirow{15}{*}{$\begin{array}{l}\text { Insecticides/miticides/ } \\
\text { nematicides }\end{array}$} & Abamectin & Toxic to fish, mammals, and aquatic organisms \\
\hline & Aldicarb & Acute oral toxicity and groundwater contamination \\
\hline & Bifenthrin & Toxic to fish and aquatic organisms \\
\hline & Chlorpyrifos & Toxic to fish, aquatic invertebrates, small mammals, and birds \\
\hline & Chlorethoxyfos & Acute human, avian, and aquatic invertebrate toxicity \\
\hline & Cyfluthrin & Toxicity to fish and aquatic organisms \\
\hline & $\begin{array}{l}\text { Cypermethrin and zeta- } \\
\text { cypermethrin }\end{array}$ & Toxicity to fish and aquatic organisms \\
\hline & Deltamethrin & Acute toxicity and toxicity to fish and aquatic organisms \\
\hline & Dicrotophos & Acute oral, dermal, and inhalation toxicity and risks to wildlife \\
\hline & Diflubenzuron & Toxicity to aquatic invertebrate animals \\
\hline & Disulfoton & Acute toxicity \\
\hline & Emamectin-benzoate & Toxic to fish, mammals, and aquatic organisms \\
\hline & Endosulfan & Acute toxicity to humans, aquatic organisms, and avian species \\
\hline & Esfenvalerate & Toxicity to fish and aquatic organisms \\
\hline & Ethoprop & Acute dermal, primary dermal, and primary eye toxicity \\
\hline
\end{tabular}




\begin{tabular}{|c|c|c|}
\hline Pesticide type & Active ingredient & Reason(s) for restriction \\
\hline \multirow{15}{*}{$\begin{array}{l}\text { Insecticides/miticides/ } \\
\text { nematicides (continued) }\end{array}$} & Fenbutatin-oxide & Acute human toxicity and very high toxicity to aquatic organisms \\
\hline & Fenpropathrin & Toxicity to fish and aquatic organisms \\
\hline & Fipronil & Toxicity to aquatic invertebrates \\
\hline & Gamma-cyhalothrin & Toxicity to fish and aquatic organisms \\
\hline & Lambda-cyhalothrin & Toxicity to fish and aquatic organisms \\
\hline & Methamidophos & Acute dermal toxicity and residue effects on avian species \\
\hline & Methiocarb & Toxicity to fish, birds, and aquatic organisms \\
\hline & Methomyl & High acute toxicity to humans \\
\hline & Naled & Eye and skin corrosivity hazard \\
\hline & Oxamyl & Acute toxicity and toxicity to birds and mammals \\
\hline & Permethrin & Toxicity to fish and aquatic organisms \\
\hline & Phorate & Acute oral, dermal, and inhalation toxicity and avian hazards \\
\hline & Resmethrin & Acute fish toxicity \\
\hline & Tefluthrin & Toxicity to fish and aquatic organisms \\
\hline & Terbufos & $\begin{array}{l}\text { Acute oral, dermal, and inhalation toxicity and risks to aquatic organisms } \\
\text { and wildlife }\end{array}$ \\
\hline \multirow[t]{3}{*}{ Rodenticides } & Chlorophacinone & High acute toxicity \\
\hline & Diphacinone & Dermal toxicity \\
\hline & Zinc phosphide & Acute oral, acute dermal, and primary dermal irritation toxicity \\
\hline Wood preservative & Arsenic acid anhydride & $\begin{array}{l}\text { Acute toxicity and because this product contains arsenic and chromium } \\
\text { compounds, which may be associated with tumor development in humans } \\
\text { and are considered to have an acute toxicity level }\end{array}$ \\
\hline Piscicide & Rotenone & Acute inhalation, acute oral and aquatic toxicity \\
\hline Molluscicide & Niclosamide & $\begin{array}{l}\text { Aquatic organism toxicity, need for specialized equipment and highly } \\
\text { specialized applicator training }\end{array}$ \\
\hline
\end{tabular}

